\title{
A VÁROSPOLITIKA VÁLTOZÁSA ÉS AZ ELŐVÁROSOK HELYZETE PÁRIZSBAN ÉS BUDAPESTEN (1850-1949)
}

(Transition of the urban policy and the situation of the suburbs in Paris and Budapest [(1850-1949])

\section{KERESZTÉLY KRISZTINA}

A mai értelemben vett külváros Európában a 19. században lezajló ipari forradalom hatására született meg. Az ipari beruházások és a nagyarányú népesség-bevándorlás miatt a város addigi területe túl szüknek bizonyult a megnövekedett igények kielégítésére. A városi infrastruktúra mind több eleme lépett át a városfalon (ez kezdetben a környezetet erósen szennyezó ipari létesítményeket, illetve a megnövekedett területigényü beruházásokat érintette, de napjainkban már a harmadik szektorra és a közhivatalokra is kiterjed). A városmag fejlödése és a beruházások kitelepülése a városi népesség egy részének kivándorlását is magával vonzotta: az egyre dráguló városi élettel és lakáshiánnyal szemben a városkơrnyéki területek olcsóbb megélhetést és helybeni munkalehetóséget kínáltak.

Az elóvárosok gyors növekedése a 19. század végén azonban nem járt együtt azok tervezett kiépítésével. A kiköltöző lakosság ezért továbbra is a város infrastruktúráját, az ott található kulturális, egészségưgyi vagy gazdasági létesítményeket használta mindennapi életében. Az elóvárosok benépesülésével tehát nem oldódott meg az eredeti probléma: a város túlterheltsége. Söt, a városi adózástól mentesült, de a város adta elónyöket kihasználó elövárosi lakosság jelenléte egy újabb problémát szült, a város és környéke közötti (gazdasági, kulturális és politikai) ellentéteket.

A városmag és a külterületek egymásra utaltsága fejlödésük során mind sürgetöbbé tette az őket szembeállító ellentétek rendezését. A város tủlterheltsége mindaddig nem szünhetett meg, amíg a környék infrastrukturális ellátottsága meg nem oldódott. Ez azonban úgyis, mint az előváros ,szülőatyja”, s úgyis mint annál jóval fejlettebb és rendezettebb egység - a város feladatává vált. A városkörnyék rendezése ezért a várospolitika, a városrendezés hatáskörébe került. Az elővárosok helyzetének alakulása tehát szorosan összefonódik a várospolitika irányvonalainak változásaival, hiszen fejlödésük nagy részben a város által elvégzett - vagy el nem végzett - szabályozásoktól függ.

E cikk a várospolitika változásain keresztül próbálja megvizsgálni a város környékének fejlödését, a város és elövárosai közötti kapcsolatok alakulását. Ehhez két város, Párizs és Budapest mintegy százéves fejlödésének mozzanatait fogjuk végigkővetni a párizsi haussmannianizmus megszületésétól (azaz az 1850-es évektől) 1949-ig, az államszocialista várostervezés bevezetéséig Budapesten. 
E két, Európa különböző régióiban elhelyezkedỏ város várospolitikája ezen időszakban hasonló válaszokat adott az elövárosok fejlödése során felmerülő problémákra, kezdve a 19. századi haussmanni „monumentális”, hatalmi érdekeket szolgáló, az elővárosokat elhanyagoló városépítéstól a 20 . század közepén megszülető, a várost és külterületeit egyaránt érintő általános városrendezési tervekig. A párhuzamos fejlődés 1949-ben szakadt meg: míg a párizsi agglomeráció rendezése a korábbi elveket követve haladt tovább, addig ugyanez Budapesten más keretek közé, az elsősorban állami érdekeket szolgáló, újjáalakított közigazgatás hatáskörébe került.

A várospolitika fejlodése a 19. század második és a 20. század első felében sok európai nagyváros történetében többé-kevésbé hasonlóan játszódott le. Célunk azonban nem egy általánosan érvényes séma felállítása, csupán egy „ötlet” felvetése, melyet két, Európa különböző szegletében lezajlott városfejlődési folyamat összehasonlításával szeretnénk bemutatni.

A két nagyváros Párizs és Budapest egyaránt egy-egy monocentrikus ország központjai. Elövárosaik kialakulása hasonló ütemben, de fáziskülönbséggel zajlott. A párizsi agglomeráció belső gyürủje (,petite couronne”) a századfordulóra vált összefüggő, városias beépítettségủ területté. Budapesten - bár az elővárosok fejlödése a három korábbi város (Pest, Buda és Óbuda) 1873-as egyesítése után szinte azonnal megindult - ekkor még nem beszélhetünk összefưggő külvárosi ipari övezetről. A párizsi belső gyűrűnek megfelelö övezet csak a két világháború között alakult ki. Ebben az idószakban Párizs körül már egy második gyürủ (,grand couronne") jelent meg, amit azonban nem a város iparosodása következtében történő gyárkitelepítések, hanem az alsóbb társadalmi rétegek családi házas építkezései jellemeztek. A külső agglomerációs gyürủ fogalma Budapesten is megjelent az 1930-as években, de ezt a föképp mezögazdasági jellegü területet a városrendezés sokáig a fôváros „védóövezetének” tekintette, s csak az 1960-as évektöl váit jelentős ipari központokkal rendelkezó övezetté. ${ }^{1}$

E fáziskülönbség ellenére a várospolitika változásának egyes szakaszai nagyjából egyidöben zajlottak le a két városban. A haussmanni városrendezés időszaka Budapesten két évtizedes késéssel jelentkezett Párizshoz képest. Az elővárosok rendezésének kérdése azonban már nagyjából egyszerre, a századforduló környékén merült fel mind a francia, mind a magyar fővárosban.

A francia fővárost körülvevó terulietek beépulése már a város iparosodása elött, a 19. század első felében megindult. A város nyugati határterületein lefektetett elsö vasútvonalak mentén ekkor a városi középosztály építkezései jelentek meg. Az elővảrosok - bár még korántsem olyan sủrủ és városias beépítettséggel, mint a késöbbi évtizedekben tehát már ekkor is léteztek, s ezt megerősíti, hogy Párizs és környéke már a francia forradalom óta különálló közigazgatási egységet képezett. Szajna megye, melynek területe nagyjából lefedte a késöbb beépülő belső gyủrüt, három kerületet, Párizs városát, SaintDenis-t és Sceaux-t foglalta magában (1. ábra). ${ }^{2}$

Budapest környékét ugyanakkor, a három város egyesülésekor még csupán néhány ezer vagy néhány száz fơs falvak jellemezték, melyeknek elóvárossá fejlödése csak az ezt kö- 


\section{1. ÁBRA}

Párizs és elövárosainak közigazgatási helyzete a francia forradalomtól 1964-ig

(The administrative situation of Paris and its suburbs from the

French Revolution to 1964)

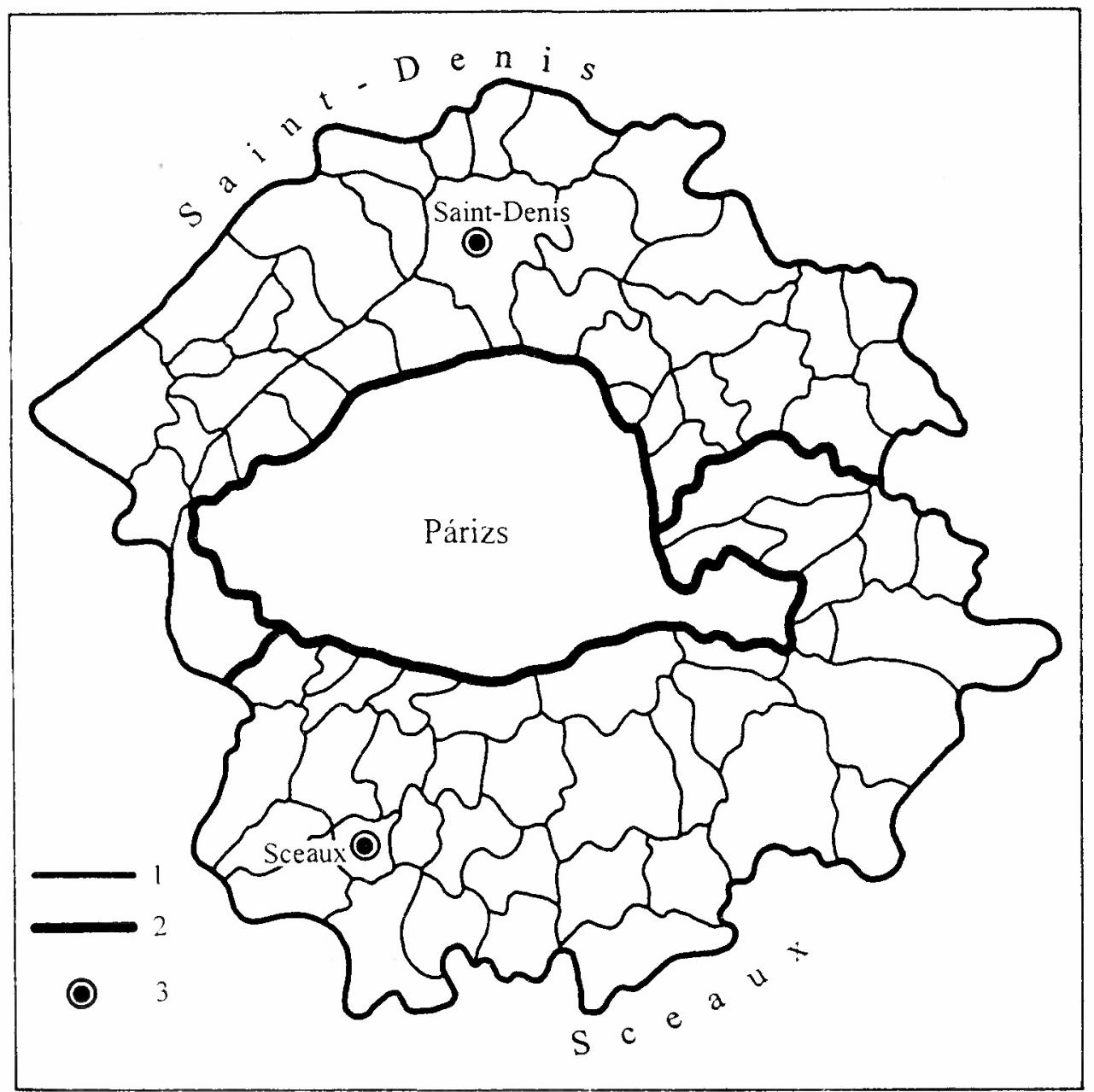

Jelmagyarázat: 1-Szajna megye határa; 2 - a kerületek közigazgatási határa; 3 -kerületközpont.

Forrás: Soulignac. 1: (1993) La banlieue parisienne. La Documentation Française, Paris, 9. o. 
vető időszakban, a városi iparosodással szoros.összefüggésben indult meg. A gyorsan iparosodó községek (összesített népességük 1866-ban még csak 20 ezer, 1900-ban viszont már 126 ezer) városiasodásuk ellenére továbbra is Pest megye fennhatósága alá tartoztak, $\mathrm{s}$ így rendezésük kérdése mindenekelött közigazgatási problémaként merült fel. $\mathrm{Az}$ elővárosok rendezésének problémája ezért - az agglomeráció fejlettségéhez viszonyítva elöbb jelentkezett Budapesten, mint Párizsban (1-2. táblázat).

1. TÁBLÁZAT

Szajna megye népességének növekedése 1866-194633

(The growth of the population in Seine county 1866-1946)

\begin{tabular}{|c|c|c|c|}
\hline Évszám & Párizs & Saint-Denis & Sceaux \\
\hline 1866 & 1825247 & 178359 & 147283 \\
1896 & 2511629 & 475398 & 321780 \\
1921 & 2906472 & 886632 & 618587 \\
1931 & 2891020 & 1169697 & 873138 \\
1946 & 2725375 & 1132548 & 917788 \\
\hline
\end{tabular}

Forrás: Soulignac, F. (1993) 28-32. o.

2. TÁBLÁZAT

A budapesti agglomeráció népességének növekedése 1869-19493

(The growth of the population in the Budapest agglomeration)

\begin{tabular}{|c|c|c|}
\hline Évszám & Budapest & $\begin{array}{c}\text { A Budapesthez 1949-ben } \\
\text { csatolt elővárosok }\end{array}$ \\
\hline 1869 & 280349 & 20000 \\
1900 & 733359 & 126000 \\
1921 & 928996 & 303030 \\
1930 & 1006000 & 416507 \\
1949 & 1057912 & 532404 \\
\hline
\end{tabular}

Forrás: Preisich, G. (1969) 7-13.o.

\section{Fogalmak és kronológia}

A várospolitika fejlődésének szakaszait a francia város-szociológus, Alain Cottereau által javasolt fogalmak segítségével állítottuk fel. ${ }^{4}$ Cottereau szerint a párizsi várospolitika a századfordulón alapvetó változáson ment keresztül. Míg a 19. században a városrendezés Párizsban kizárólag hatalmi igényeket szolgált, addig ezt a századfordulón a 
modern, közösségi érdekeket képviselö, „tudatos” várospolitika váltotta fel. Ennek első konkrét megnyilvánulását e szerző a párizsi metró 1900-ban kezdődỏ kiépítésében látja. ${ }^{5}$

A várospolitika változásainak Cottereau által javasolt felosztását tovább finomitva annak három szakaszát különböztethetjük meg, melyek Haussmann kora és 1949 kőzött a párizsi és budapesti agglomerációk fejlödésének történetét egyaránt meghatározták.

Az ún. „hatalmi várospolitika" (,,urbanisme autoritaire”) a haussmanni városrendezéssel azonosítható. Párizsban az 1850-es évektöl a századfordulóig tartott ez a korszak, Budapesten a három város egyesítésétől az elsö világháborúig.

Erre az időszakra a város egyeduralma jellemző. A várospolitika nem foglalkozott a városkörnyék rendezésének kérdésével, s ezzel összefüggésben nem számolt a városrendezés szociális következményeivel. E „technokrata” városvezetés ugyanakkor mégis haladást képviselt az elözö korokhoz képest. $\mathrm{A}$ városépítés ugyanis az egységes városkép kialakitása mellett már a város egyéb infrastrukturális elemeinek (közmüvek, közlekedési hálózat) kezelését is figyelembe vette.

A második szakasz átmenetet jelentett a hatalmi várospolitikából a „tudatos várospolitikába". A városrendezésben ekkor jelent meg elöször a szociálpolitika, illetve az agglomeráció rendezésének gondolata. Egyelöre azonban e tárgyban, az elképzelések körüli vitákon kívül, kevés gyakorlati eredmény született, $s$ így az elövárosok épp ebben az időszakban élték meg legrendezetlenebb fejlődésüket. Ez Párizsban a századfordulótól az 1930as évekig, míg Budapesten a második világháború végéig tartott.

A városkörnyék rendezetlen növekedése végül a törvényhozás beavatkozását követelte meg. A „tudatos várospolitika” (,,urbanisme volontaire”) kezdeteként az 1930-as években mindkét országban meghozták az első általános, a várost és elövárosait egyaránt érintö városrendezési törvényeket, majd Párizsban 1934-ben, Budapesten 1947-ben megszülettek az első általános városrendezési tervek, melyek az elövárosokat már összefüggő, a várossal koherens egységet képezö területként kezelték.

\section{Monumentális városépités - a haussmanni várospolitika a 19. században}

A Budapesten és Párizsban az elmúlt század második felében lezajló nagy városépítkezések közötti párhuzam ismert jelenség. Haussmann hatása Budapestre Bécs közvetitésével érkezett. ${ }^{6} \mathrm{~A}$ sủrü, keskeny utcákkal átszött középkori város egységes, modern városképének kialakítása Párizsban 1853 (Haussmann beiktatása) után, Budapesten pedig 20 évvel késöbb, a fơváros egyesítését követően indult meg.

A nagy közterek, középületek kiépítése mindkét városban a hatalmi demonstrációt szolgálta. Budapesten a haussmanni építkezések a kettős Monarchia másik fövárosához, Bécshez való felzárkózást segítették.

A párizsi és a budapesti városfejlesztések közötti hasonlóságot legnyilvánvalóbban a két városban kiépített kör- és sugárútrendszer mutatja. De ugyanúgy Haussmann hatására utalnak Budapesten a monumentális középületek (a legismertebbek az Akadémia, az 
Opera, az Országház, a Tózsde, a Vigadó épülete, melyek a párizsi Operával, különböző színházakkal [Théâtre de Châtelet, Théâtre de la Ville stb.] hozhatók párhuzamba), a parkok (a Városliget, a Dunakorzó, melyeknek Párizs leghíresebb, Haussmann korában létesített parkjai, a Boulogne-i erdö, a Vincennes-i erdő, a Montsouris-park stb. felelnek meg) és a csatornahálózat kiépítése. ${ }^{7}$ E fejlesztéseket Párizsban a Világkiállítások (1878, 1889,1900 ), Budapesten pedig a Millennium lendítette elöre. ${ }^{8}$

A monumentális építkezések mellett azonban a városrendezés sem Párizsban, sem $\mathrm{Bu}$ dapesten nem oldotta meg a népesség gyors növekedéséből és az iparosodás folyamatából eredő problémákat. Az elóvárosok rendezésének kérdése ebben az idóben csak akkor merült fel, amikor arra a város belső rendezése miatt feltétlenül szükség volt. Az elóvárosok még nem számítottak állandóan fejlödő, összefüggő területnek. Ez az „elhanyagolo", „önző” várospolitika mindkét fóvárosban jellemzỏ volt.

\section{Párizs közvetlen környékének 1859-es beolvasztása}

A Párizs körül 1791-ben létrehozott vámhatár a fóváros környékén elhelyezkedö településeket megfosztotta a város nyújtotta kiváltságoktól. 1841 és 1844 között egy katonai védőrendszer épült Párizs köré, a város határán kívül. Ez a két határvonal a közéje szorult 24 település fejlỏdését mind a város, mind a távolabbi elóvárosok irányában elvágta. A községek sorsáról ekkor megkezdődő viták húsz évig tartottak. A városvezetés fölöslegesnek tartotta a települések Párizshoz csatolását, mivel az túl sok áldozatot követelt volna a város részéröl.

Az egyesítés, bár elkerülhetetlen volt, csak akkor jött létre, amikor azt a város érdekei megkívánták. Párizs lakossága 1841 és 1861 között 640 ezer fỏvel emelkedett, s az igy „,megtelt” föváros további fejlesztéséhez uj területekre volt szükség. Haussmann a várost övezỏ települések beolvasztásával több mint kétszeresére növelte a város területét.

A hozzácsatolás hatalmas anyagi áldozatok árán (a telepủlések városi infrastruktúrájának, közigazgatási rendszerének kiépítését a városnak kellett finanszíroznia, s Haussmann jelentős hitelek felvételére kényszerült, ami vẻgül politikai pályafutását is tönkretette) megoldotta a város és az egykori külvárosok fejlödésének problémáit. Az akkor alakulóban lévő távolabbi elövárosok helyzetét azonban inkább súlyosbította az egyesítés. Azok a néprétegek (munkások, kézmủvesek, újonnan bevándorlók), amelyek addig a volt külvárosokba települtek, ettől kezdve nem tudták tartani a városi életszínvonalat és kénytelenek voltak a várost körülvevő védőfalon kívüli területekre költözni. E külső telepủlések egyre gyorsabb ütemú növekedése azonban még tőbb mint fél évszázadon át - a védőrendszer 1920 és 1924 közötti lebontásáig - a fóvárostól teljesen elszigetelten zajlott. ${ }^{9}$ 


\section{A Fövárosi Közmunkatanács alapítása Budapesten}

Az elövárosok rendezése a 19. században Budapesten is csak a várost közvetlenül érintő esetekben merült fel. Ezt mondta ki a Fővárosi Közmunkatanács megalapításáról szóló 1870: X. törvénycikk 15. paragrafusa: „Amennyiben azon munkálatok, melyeknek tervezése és vezetése e törvény szerint a fövárosi közmunkák tanácsát illeti, oly területekre is kiterjednének, amelyek Pest és Buda városok fennhatósága alatt nem állnának, ezen területek az érintett szabályozási munkákat illetőleg a fövárosi közmunkák tanácsa alá rendeltetnek...". Ezen elő́rás tehát - mely végül soha nem valósult meg a gyakorlatban - nem az elövárosok rendezésére, hanem a város rendezésének esetleges „meghosszabbítására" vonatkozott. ${ }^{10}$

\section{A várospolitika irányváltásának kezdete}

A városrendezés valójában a 20. század elején kezdett felfigyelni az elővárosok fejlódésének problémájára. Míg Párizsban a rendezetlen körülmények között kialakult, de már teljesen városias formát öltött belső gyürủ közegészségügyi és szociális problémái, addig Budapesten a várost és környékét elválasztó közigazgatási nehézségek indították el ezt a folyamatot. Az ekkor még csak tervek szintjén megjelenő megoldások mindkét városban több évtizedig tartó viták kiindulópontjai lettek.

\section{Budapest - az 1908-as Bárczy-Harrer-féle tervezet}

A Budapest körül elhelyezkedő községek közigazgatási hovatartozása a századfordulóra vált problematikussá. Bár ebben az időben még nem beszélhetünk összefüggő elövárosi övezetről, néhány település (Újpest, Csepel, Budafok) ipari jellege, s ezáltal a fövároshoz füződő szoros kapcsolata nyilvánvaló volt. ${ }^{11}$

A Budapest szomszédságában, de a föváros közigazgatási rendszerétöl elszigetelten fejlödő községek problémájának megoldására több kísérlet történt a századforduló óta. 1901-ben Pest vármegye kérelmezte kilenc település ${ }^{12}$ Budapesthez csatolását. A kezdeményezést ekkor a föváros ellenállása hiúsitotta meg. 1907-ben viszont a föváros tett kísérletet az éppen rendezett tanácsú városi rangot kapott Újpest beolvasztására. Ezt viszont ez utóbbi akadályozta meg, ragaszkodva önállóságához és olcsóbb közigazgatási rendszeréhez. ${ }^{13}$

Az elszigetelt próbálkozások után Harrer Ferenc 1908-as tervezete volt az elsö, mely az elővárosok helyzetét részletesen megvizsgálva tett javaslatot a közigazgatás megreformálására. Bárczy István polgármester felkérésére Harrer harminc Budapest környéki község állapotát vizsgálta meg. Első kritériuma a települések városiasságának foka volt, melyet a házak állapota (azaz az emeletes házak aránya), a mezógazdasági és a beépített 
területek aránya, a lakosság foglalkoztatottsági összetétele, valamint az ott található gyárak száma szerint határozott meg. A másik kritériumot, a községeknek a fỏvároshoz füzödő kapcsolatát, a tömegközlekedés és az áruforgalom alapján osztályozta. Vizsgálódása után kilenc települést emelt ki (Újpest, Rákospalota, Rákosszentmihály, Rákosfalva, Kispest, Erzsébetfalva, Albertfalva, Budafok és Kistétény), melyek fejlettsége lehetővé tette, hogy teljes egészében a városhoz csatlakozzanak. A maradékot - a tervek szerint - csak törvényhatóságilag kapcsolták volna Budapesthez, vagyis bár Pest megyétöl a fövárosi törvényhatóság alá kerültek volna, továbbra is megtarthatták volna olcsóbb közigazgatási rendszerüket.

A reform egyetlen ellenérve - Harrer szerint - a fővárosra háruló hatalmas anyagi teher lehetett. Ezt azonban ö - $\mathrm{s}$ ebben rejlik a tervezet reformjellege - hosszú távon megtérülö beruházásnak tekintette, hozzátéve, hogy a városnak a bekebelezés amúgy sem jelentene sokkal nagyobb kiadásokat, mint amiket már addig is vállalt a községekkel való szoros kapcsolatából kifolyólag. ${ }^{4}$

A tudatos városrendezés ezen elsó megnyilvánulása azonban olyan erős ellenállásba ütközött a föváros részéről, hogy a tervezetet végül soha nem tárgyalták. Hogy miért volt ez a tervezet úttörỏ jellegú, azt a vele könnyen párhuzamba állítható Haussmann-féle egyesítéssel összevetve lehet igazán megérteni. Haussmann 1859-ben egy eleve meghatározott, fallal körülvett területet csatolt Párizshoz; az egyesítést tehát semmilyen, a településekre vonatkozó felmérésnek nem kellett megelöznie. A hozzácsatolással kapcsolatos kiadásokat pedig - hogy Harrer szavaival éljünk - azonnal megtérülő beruházásnak kell tekinteni, hiszen a városnak mindenképpen bövitenie kellett a területét. Az egyesítés azonban - éppen a „tudatosság” hiánya miatt - nem oldotta meg a távolabbi elövárosok helyzetét: az 1841-es védőfal ezután áthághatatlan határt jelentett a város és az azt körülvevö települések között.

Harrer javaslata viszont, mely széles körü elözetes vizsgálaton alapult, a bekebelezésre szánt területen kivülrekedt községeket sem hagyta volna teljesen magára: bár meghagyta számukra az önálló fejlődés lehetóségét, bizonyos közigazgatási szinten mégis a város érdekkörébe kivánta vonni öket.

\section{Párizs - az urbanizmus megszületése}

A haussmanni várospolitika nemcsak a párizsi elővárosok fejlỏdését hanyagolta el, de magában a fóvárosban sem foglalkozott a lakáshelyzettel. Az egyre szükülö lakáspiac miatt mind szélesebb rétegek szociális helyzete vált kritikussá. Egy részük a szük városi keretet elhagyó gyáripart követve az elövárosokba költözött, más részük továbbra is a falakon belül maradt - egyre embertelenebb körülmények között. A városban eluralkodó lakáskrízis és a külvárosok rendezetlen növekedése a századfordulón szociális mozgalmat indított el. Egyes kutatók ezt az időszakot tekintik az urbanizmus, azaz a várostudomány 
megszületésének, mivel ez volt az első alkalom, amikor a várostervezést már nemcsak az építészet, hanem egyéb - szociális, ökonómiai - szempontok is irányították. ${ }^{15}$

A városi nyomor hatására kialakuló új várostervezés nem egyedülállóan francia jelenség. A 19. század végén Angliában merült fel először a gondolat, hogy a gyors iparosodásból következő társadalmi krízisért, falu és város végleges kettészakadásáért egyértelmúen a város, az urbanizáció a felelős. A válság megoldása az új várostervezés szerint az „emberibb lakókörnyezet” kialakítása volt: a városi embert vissza kell helyezni a természet, a család harmóniájába; vissza kell állítani város és vidéke egységét. Ezt a gondolatot képviselte Ebenezer Howard kertváros-mozgalma, s ennek hatására merült fel Párizsban a város falain kivuuli területek rendezése. ${ }^{16}$

Párizsban a lakäskrízis kiváltotta elsó reakciók az 1870-es kommün idejére datálódtak. Ekkor alakultak meg a párizsi munkások első bérlö-szakszervezetei. E mozgalom érte el, hogy az 1889-es világkiállitáson külön pavilont szenteltek a lakáskérdésnek, s hogy a következö években önálló szervezet alakult az olcsó lakások építésére (Société Française des Habitations a bon marché), mely egy 1894-es törvény alapján állami támogatásban részesült. Ezek a törekvések azonban távolról sem javítottak a lakáskrízisen: Párizsban 1914 elött összesen kétezer lakás épült e rendszer alapján. ${ }^{17}$

A századfordulón meginduló új városépítő mozgalom tehát egyéb megoldásokat keresett: a munkáslakások építését a város határain túl, megfelelő egészségügyi és környezeti körülmények között kívánták megvalósítani.

Georges Benoût-Lévy honositotta meg Franciaországban E. Howard kertváros-mozgalmát, mely a két világháború között húszezer új lakást biztositott ugyan, de ezzel még mindig nem tudták felvenni a versenyt a betelepülök egyre növekvő számával. A főváros és környéke elszigeteltségének enyhítését szolgálta egy másik terv: a Párizst körülfogó erődrendszer lebontása és helyére zöldövezeti sáv telepítése, mely a föváros „tüdejének” szerepét kapta volna.

$\mathrm{Az}$ erődrendszer lebontásának és rendezésének gondolata még tovább vezetett: felmerült az igény egy olyan szerv létrehozására, mely Párizs körül tíz kilométeres körzetben irányítaná a területrendezést. Bár az elképzelés elöször mind a városi elöljáróság, mind az állam részéröl heves ellenállást váltott $\mathbf{k i}$, a környék rendezésének sürgető volta miatt mégis megvalósult. 1910-ben Dausset, Szajna megye elöljárója megalakította Párizs környékének városrendezési bizottságát (Commission de l'Extension de Paris), melynek célja a párizsi külvárosok anarchikus növekedésének megfékezése volt. ${ }^{18}$

A bizottság terve alapján a várost körülfogó katonai zónát zöldövezeti sávvá alakították volna, s a Szajna megyében építendö munkáslakásokat szintén zöldterületek, parkok, sétányok és kertvárosok övezték volna. Az elővárosi közlekedést egy kör formájú és ahhoz kapcsolódó sugárirányú úthálózattal kívánták megreformálni. A terv megvalósítása azonban az elsỏ világháború miatt elmaradt.

1919-ben újabb terv született, ezúttal a Szajna megyében létrehozott Párizs környéki igazgatóság (Direction de l'Extension de Paris) irányításával. A későbbi városrendezési tervek alapgondolatát elörevetítö tervezet az elövárosi ipari területeket zónákra osztotta, 
és felvetette három ủj város építését. A közlekedést helyi érdekủ expresszhálózat (RER) kialakításával oldották volna meg. Ez a terv is meghiúsult, mivel a szenátus visszautasította a szükséges hitelek folyósítását. ${ }^{19}$

\section{Párizs és Budapest — ,elhanyagolt" elövárosok}

Az elővárosok szerepének felismerése és az erre vonatkozó tervek a 20. század elején mind Párizsban, mind Budapesten csupán elvi jelentőségủek maradtak: a még erôsen konzervatív városvezetés mindkét fỏvárosban megakadályozta a külterületek következetes rendezését. Az első világháború és az azt követő újabb bevándorlási hullám pedig e kezdeti próbálkozások, tervek értelmét is megkérdőjelezte. Az elövárosok növekedése a két világháború között még nagyobb ütemben, még rendezetlenebbül folytatódott, s ez annál is súlyosabb következményekkel járt, mivel ez volt az az időszak, amikor az agglomeráció növekedésében - a városok népességszámának fokozatos stagnálásával párhuzamosan - az elóvárosok vették át a vezető szerepet.

Párizs lakosságszáma az 1920-as évektől kezdve csökkenö tendenciát mutatott, míg a Szajna megyéhez tartozó további két kerület (Saint-Denis és Sceaux) növekedése az eddigi ütemben haladt tovább (2. ábra). A párizsi agglomeráció kiterjedése ugyanakkor a két világháború között lépte túl Szajna megye határait.

Az 1920-as, 1930-as években lezajlott nagyarányú növekedés az ipari fejlödés hirtelen megugrásának volt a következménye. Párizs és környéke az elsö világháború alatt az ország vezető ipari központjává vált. Az ipartelepítés számos, addigi agrár jellegú területet is érintett. ${ }^{20}$

Az ipar növekedése, a föváros központi szerepének erősödése, valamint a háború utáni társadalmi mobilitás minden eddiginél nagyobb bevándorlási hullámot eredményezett. A világháború után mintegy egymillió menekülöt kellett lakáshoz juttatni Párizs környékén. Ez fokozta az addig is súlyos lakáshiányt, melyen az 1920-as és 1930-as évek lakásépitései (a szociális lakások és a kertvárosok létesítése) nem tudtak segíteni.

E helyzet „megoldásaként” 1920 és 1939 között zajlott le a Párizs távolabbi környékén eddig még érintetlen területek önkényes felparcellázása és olcsó családi házakkal való beépitése: 250 ezer telek 700 ezer embernek nyújtott ily módon lakáslehetőséget. Az újonnan felparcellázott területek a város körül már beépített kis gyürün kívül, a vasútvonalak mentén radiálisan helyezkedtek el. Mig a múlt században beépült kis gyűrú lakosságának egy része még tehetősebb, polgári származású családokból állt, addig a távolabbi elövárosok népessége szinte kizárólag alsóbb társadalmi osztályokból, külföldi bevándorlókból, fiatal munkáscsaládokból tevődött össze.

A párizsi elóvárosok képét máig erỏsen meghatározó építkezések mindenféle tervezés, összefogó rendezö elv nélkül zajlottak le. A szabad terïleteket nagy ingatlanủgynökségek vásárolták fel és adták tovább a parcellázásokkal foglalkozó társaságoknak. Ez utóbbiak a területek felosztását - a helyi viszonyokat szem elött tartó, racionális tervezés nélkül - 

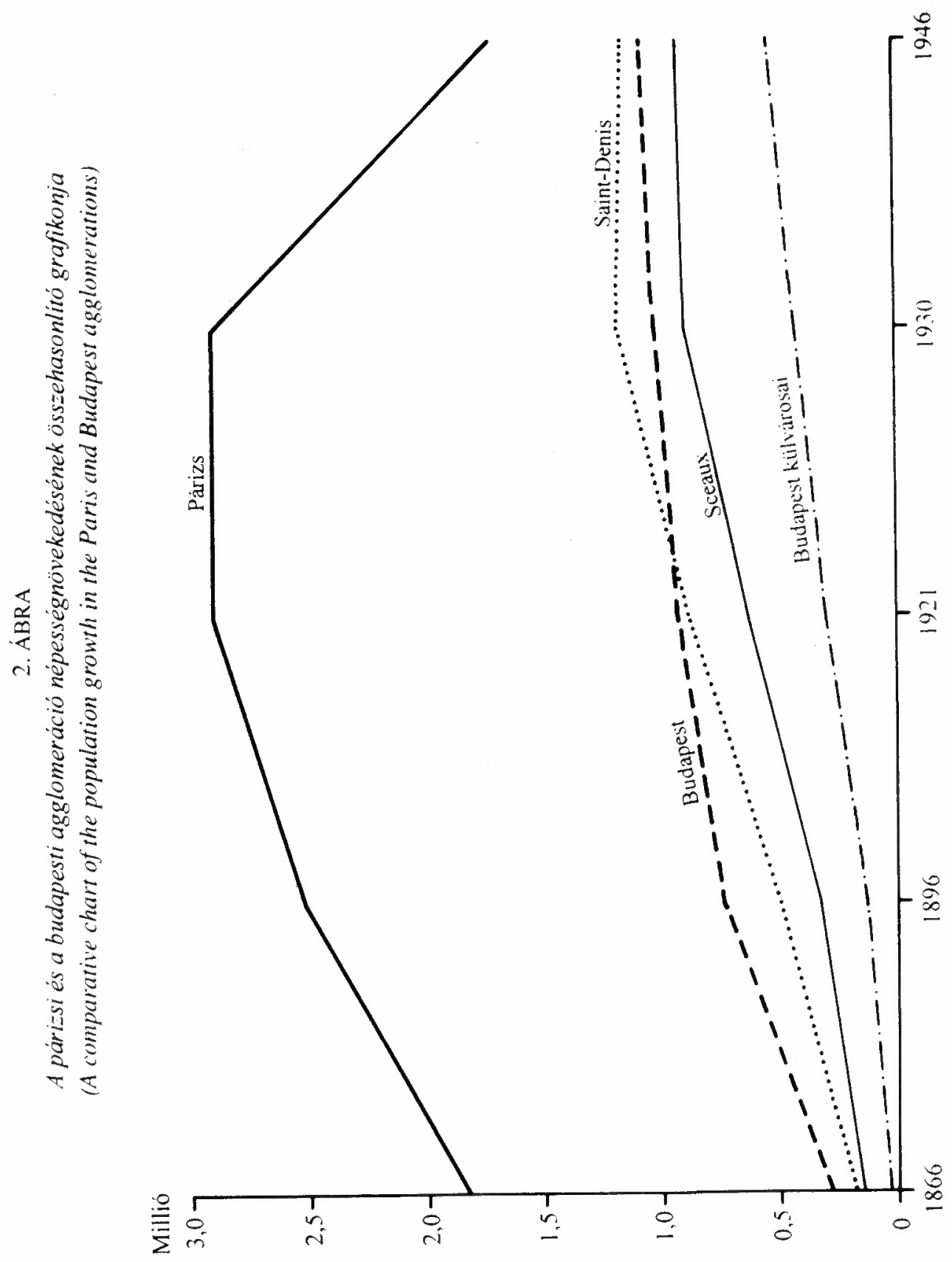
földmérökkel végeztették el. Az ezután bérbe adott parcellák infrastrukturális ellátására e társaságok már nem vállalták a felelösséget, a beépités a bérlö dolga volt. A parcellákra felhúzott nyomorúságos házakban (öt százalékuk rendelkezett négy vagy több helyiséggel, míg három százalékuk csupán kétszobás volt) gyakori volt a víz, gáz illetve villany hiánya. $^{2 !}$

Budapesten a két világháború között a föváros fokozatosan lassuló növekedése párhuzamosan zajlott az elövárosok egyre gyorsuló gyarapodásával (3. ábra). E fejlödést inkább fellendítette, hogy a trianoni békeszerzödés következtében a föváros központi szerepe az eddigieknél még jobban kihangsúlyozódott. A fontosabb erdélyi és felvidéki városok elcsatolása miatt Budapest maradt szinte az egyedüli gazdasági, kulturális és politikai központ az országban.

A fővárosi ipar fejlódése fellendítette az elővárosok növekedését is. Az 1920-as évektöl kezdett kialakulni a városkörnyék nehézipari jellege. A két világháború között az egész országban csak Budapesten nỏtt a munkahelyek száma, ami megmagyarázza a bevándorlás egyre nagyobb mértékét. E tendencia - Párizzsal ellentétben - a gazdasági válság idején sem szakadt meg: az ipari válsággal egyidőben zajló agrárválság miatt ebben az idöben 25 százalékkal növekedett az újonnan érkezettek száma. Az 1930-as évektöl kezdve pedig a háború előtti konjunktúra hatására folytatódott a növekedés. A két világháború között tehát Budapest körül is kialakult egy összefüggő ipari övezet. ${ }^{22}$

Az ipari fejlödés és a lakosság beáramlása ellenére sem indult meg a Budapest környéki települések városiasodása. Az elővárosok közellátottságáról Szendy Károly polgármester (1934-1944) 1942-es tanulmánya ad képet. Az általa vizsgált 24 településből 23 a második világháború elején mindössze két község, Kispest és Újpest részesült a fövárosi gázellátásban. A villlamos áramot mindegyik városba és községbe bevezették. A csatornahálózat viszont csupán Újpestet, Sashalmot, Kispestet, Pesterzsébetet és Budafok egy részét érintette. A városkörnyéki házaknak 21,6 százaléka volt vízzel ellátva, míg ugyanez az arány Budapesten 85,2 százalékot tett ki. ${ }^{24}$

\section{A várospolitika eredménytelensége a két világháború között}

Az elövárosok egyre gyorsuló ütemú növekedése két dolgot tett nyilvánvalóvá a 20. század 30-as éveire. Egyrészről azt, hogy - és ez elsősorban Budapest esetében volt fontos, ahol a községek és a föváros között semmilyen „törvényes” kapcsolat nem volt - a városkörnyék fejlödése, annak megszervezése nem fưggetleníthetỏ a várostól. Másrészröl pedig, hogy az elövárosok rendezését csak átfogó, a külterületeket egységesen érintö intézkedéssel lehet megoldani. Ehhez a felismeréshez azonban számos sikertelen próbálkozáson és vitán keresztül jutott el a várostervezés mind a két országban. 


\section{3. ÁBRA}

Kis-Budapest és környéke 1950 elött

(Smaller Budapest and its environs before 1950)

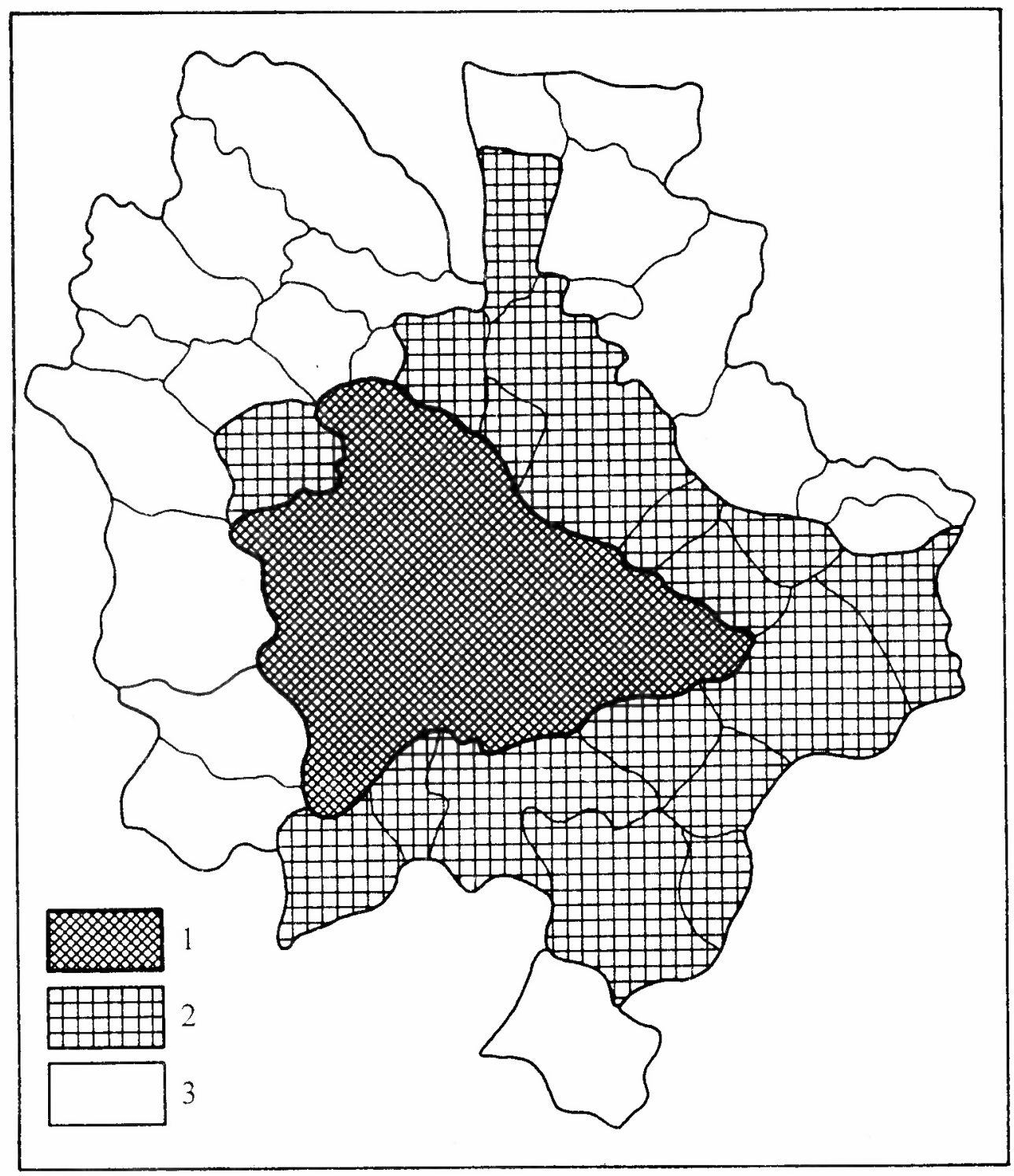

Jelmagyarázat: 1 - Budapest 1950 elött; 2 - 1950-ben Budapesthez csatolt települések; 3 - Az elöbbiek mellett 1938-as és 1941-es BM. rendeletek által Budapest környékének nyilvánított települések. 


\section{Budapest - viták az elốvárosok sorsáról}

A budapesti külvárosok helyzetének kérdése - Harrer sikertelen 1908-as kísérlete után - az első világháborút követően egy darabig lekerült a napirendröl. Trianon és a Tanácsköztársaság után a föváros elzárkózása az elővárosoktól csak tovább erösödött. Egyrészt, a világháború után ,megcsonkított” országban a 900 ezer föt számláló föváros már így is „vízfej” volt az országban, a községek hozzácsatolása tehát nem jöhetett szóba. Másrészt a többnyire munkáslakta elővárosok a konzervatív vezetésủ város szemében alapvető veszélyt jelentettek.

Az elővárosok elhanyagolásának legföbb oka azonban nyilvánvalóan az volt, hogy a két világháború között még mindig a föváros városképének rendezése állt elötérben. (Ekkor zajlott a dunai rakpartok, a fontosabb útkeresztezödések - az Astoriánál, a Gellért téren, az Andrássy út és a Kiskörút találkozásánál stb. --, a budai hegyek, valamint Lágymányos és Erzsébetváros rendezése.) $)^{25}$

A városkörnyék problémáját ismét Harrer Ferenc vetette fel. 1933-ban készült városfejlesztési programjának célja eredetileg egy a főváros belső rendezésére szolgáló keretterv volt. Ez önmagában is egyedülállónak számitott, hiszen Budapest kiépítését addig semmilyen általános tervezet nem szabályozta. A tanulmány rendszeresen tárgyalja a fôváros egységes rendezésének különböző feltételeit: a közlekedés, a lakóházépítés és vele összefüggésben a lakóövezetrendszer, a zöld területek, a középületek valamint a különleges városépítési problémák - a Vár, a belváros rendezésének - megszervezésére ad javaslatokat. A konkrét program kialakításának alapfeltétele azonban - írja Harrer --, hogy eldöntsék, miként alakuljon a város és környéke viszonya. Tanulmánya bevezetôjében négy lehetőséget ajánl ennek rendezésére:

1) A külvárosok teljes bekebelezése, amire azonban a város anyagi lehetőségei az adott pillanatban nem adtak lehetőséget.

2) A városkörnyék és a föváros egy közigazgatási egységbe olvasztása, a községek bizonyos fokú önállóságának megtartásával. A Párizs példáját követő megoldást „Új-Budapestnek”, vagy „Budapest megyének” lehetne nevezni.

3) Az elővárosok és a város egységesitése meghatározott rendezési feladatokra korlátozva. Az „összekötő” szerepét a Fövárosi Közmunkatanács látta volna el, az 1870-es törvény ben meghatározott jogai alapján.

4) A két terület együttmúködése meghatározott rendezési munkálatokban, közigazgatási önállóságuk megtartása mellett.

Harrer Budapest megye létrehozását tartotta a legideálisabb megoldásnak, mivel ez biztosította volna a főváros és a külvárosok közötti együttmúködést, ami a városnak sem jelentett volna túl nagy anyagi áldozatot. ${ }^{26}$

A tanulmány hosszú vitasorozatot indított el. A föváros és Pest megye egyaránt ellenezték az elövárosok és a város közötti szorosabb kapcsolatok kialakítását. Sipöcz Jenó (1934-ig Budapest polgármestere) egyáltalán nem látta időszerünek a városkörnyéki települések és a föváros összekapcsolását. A még csak kialakulóban levő városi polgári 
társadalomra szerinte rossz hatással lett volna a községek alacsony társadalmi színvonala. Közigazgatási összekapcsolásukat ezért - elképzelése alapján - az akkorinál sokkal szorosabb gazdasági és társadalmi összefonódásnak kellett volna megelőznie. ${ }^{27}$

Pest megye és a vidéki városok szintén nem támogatták Harrer javaslatát. Attól féltek, hogy a város és az elővárosok összekapcsolása még nagyobb fölényhez juttatná Budapestet az ország többi részével szemben. A legszélsőségesebb vélemények szerint az elővárosok nem is léteztek, csupán politikai fogalmak voltak, melyeket azért találtak ki, hogy egy Bécshez vagy Párizshoz hasonlóan erős politikai központot hozzanak létre Budapesten is. 28

A parázs viták ellenére az elóváros-probléma megoldására még jó pár évig nem került sor. A párizsi agglomeráció haussmanni egyesítését vagy a párizsi metró kiépítését megelözó vitákhoz hasonló helyzet alakult ki Budapesten az 1930-as években.

Párizs — törvények a városkörnyék önkényes felparcellázása ellen

A párizsi elövárosok rendezését, az egyre súlyosabb lakáskrízis megszüntetését a háború elótti szellemben folytatódó városépítési akciók nem tudták megoldani. Az 1920 és 1939 között létesített kertvárosok, melyek összesen 60 ezer lakáslehetőséget teremtettek, nem tudták felvenni a versenyt a gyorsan elterjedỏ, olcsó lakhelyeket biztosító parcellázásokkal. Ugyanakkor éppen a párizsi agglomeráció e kaotikus növekedése ébresztette rá a városvezetést a törvényi úton való közbelépés szükségességére, mely a kezdeti sikertelen kísérletek után az elövárosok általános rendezését elöíró törvényhez vezetett.

A parcellázások megfékezésére ugyan már a folyamat elején kísérletet tettek, az első törvények azonban átgondolatlanok és hiányosak voltak, ezért nem hoztak semmilyen eredményt. Az elsó városrendezési törvény 1919-ben Szajna megye összes községe és minden ezer fỏnél népesebb települése számára kötelezővé tette a városrendezési terv elkészítését, valamint épitési engedélyhez kötötte a parcellázást. Az elöirások be nem tartása azonban semmilyen szankciót nem vont maga után, így a törvény teljesen hatástalan maradt.

A második, 1924-ben hozott rendelkezés már több sikerrel járt. A parcellázás előfeltételeként rendezési terv készítését tette kötelezővé, s kimondta, hogy minden község területének egynegyedét az utak és a közellátás számára kell fenntartani. Nem határozta meg viszont, hogy mely időszakra érvényes az elöírás: a törvényt a parceilázók egyéni érdekeiknek megfelelóen alkalmazták az 1924 elótt vagy az után megkezdett parcellázásokra. Az ellentmondást egy négy évvel később hozott törvénnyel oldották fel, mely elrendelte az 1924 előtt felparcellázott területek rendezését is.

Ugyancsak 1928-ban jött létre a „Párizsi Régió Rendezésének és Általános Szervezésének Legfelsöbb Bizottsága" (Comité Supérieur d'Aménagement et d'Organisation Générale de la Région Parisienne). Ez a bizottság volt hivatva ellenőrizni a törvények 
végrehajtását, s ugyancsak ez a szervezet bízott meg egy városrendező csoportot a régió általános rendezési tervének kidolgozásával. ${ }^{29}$

A század elején megindult reformfolyamat Párizsban és: Budapesten egyaránt megosztotta a város építöinek táborát. A hivatalos városvezetés irányító elve többnyire továbbra is az elóvárosokat elszigetelt, a várostól független területként kezelő, „hagyományos”. várospolitika maradt. A városfejlesztés új módszerei, melyek az elövárosok szerepének kihangsúlyozásán alapultak, még jó darabig inkább félelmet keltettek a város vezetőiben: félelmet az elmaradott külvárosok káros társadalmi hatásától, a fejlesztésükhöz szükséges óriási anyagi áldozatoktól. A várospolitika fejlődésének előzỏ szakaszában a külterületek teljes figyelmen kívül hagyása okozta azok rendezetlen fejlödését. A második, átmeneti szakaszban viszont a kaotikus növekedés már az elövárosok szerepéröl kialakult ellentétes nézópontok miatt folytatódott. Az 1930-as évekre azonban ez a növekedés oly mértékủvé vált, hogy a városvezetésnek már nemcsak az eredeti problémákkal (vagyis Párizsban a lakáshiánnyal, Budapesten a várost és környékét elválasztó közigazgatási rendszer tarthătatlanságával) kellett szembenéznie. Ekkorra nyilvánvalóvá vált, hogy az elővárosok fejlődése semmiképpen nem függetleníthető a várostól, azaz az agglomeráció csak egységes egészként kezelhetō, s nem bontható le különálló településekre. Vagyis az elóvárosok fejlödése csakis egy egységes rendezési tervvel szabályozható.

\section{A tudatos várospolitika kezdete}

\section{Az általános törvények megszületése}

Az egységes városrendezés szükségességének felismerése, ami egyben a tudatos várospolitika kezdetét is jelentette, mindkét városban az 1930-as években hozott általános városrendezési törvényekkel jelentkezett.

Franciaországban az 1932-ben született törvény kétszintü városrendezést tett kötelezỏvé, egyrészt a községek által készített városrendezési tervek, másrészt az egész párizsi régióra érvényes általános városrendezési terv formájában. E régió területe az elöírás szerint a Notre Dame-tól húzott $35 \mathrm{~km}$-es sugarú körön belül, $3800 \mathrm{~km}^{2}$-en elhelyezkedő 657 községet foglalt magába.

Magyarországon Harrer 1933-as városrendezési programjának eredményeképpen született meg 1937-ben a „Városrendezésrỏl és az építésügyről” szóló törvény, mely minden magyar város számára kötelezóvé tette az általános városrendezési terv kialakítását. A budapesti elövárosok rendezése, az ottani épitési területek meghatározása és azok felügyelete a Fővárosi Kơzmunkatanács hatáskörébe került. ${ }^{30} \mathrm{Az}$ elövárosokat a belügyminiszter 1938-as rendeletében sorolta fel. ${ }^{31}$ 
Az általános rendezési tervek kidolgozása

Az városrendezési törvény alapján Párizsban már 1934-ben elkészült a régió általános rendezési terve. Budapesten ugyanez csak a második világháború után valósulhatott meg. A Közmunkatanács ugyan 1940-ben megkezdte a környékrendezés kidolgozását, de ez a világháború miatt nem válhatott egységes programmá. Budapest agglomerációját hét építési övezetre osztották és megindult a környék felparcellázása. A lakáshiány enyhítésére lakótelepek építését vették tervbe (Csepelen kétszáz telkes, Pesterzsébeten ezer családi házas lakótelepet). A külvárosok és a föváros közötti forgalmat tíz sugárút bonyolította volna le. ${ }^{32}$

A világháború alatt azonban számos esetben ennek ellentmondó intézkedéseket kellett hozni. Az üres telkeket a fóvárosi közélelmezési problémák miatt mezögazdasági termelésre hasznosították. Az építöanyag-hiány miatt be kellett szüntetni a régi lakóépületek lebøntását, $\mathrm{s}$ ez lehetetlenné tette a települések építészeti egységesítését. ${ }^{33}$

A háború után a Közmunkatanács újabb bizottságot küldött ki, melynek feladata a városfejlesztési program átdolgozása volt „Nagy-budapesti értelemben”. A Harrer instrukciói alapján elkészült program - a háború alatt született tervekkel ellentétben - a környék rendezésén kívül az elövárosok és a föváros közigazgatási kapcsolatát is részletesen taglalta. A program hasonló módszerek alapján készült, mint a Párizsban a háború elött elfogadott Prost-féle tervezet:

1) Az agglomeráció zónákra osztása

A fóvárosi agglomeráció területét mindkét tervezet két részre osztotta: egy városi és egy vidéki zónára. Budapesten ez egyben a városkörnyék közigazgatási helyzetének megoldását is jelentette. A fövárossal már teljesen egybeépült négy községet, Csepelt, Albertfalvát, Pesthidegkutat és Csillaghegyet Budapesthez csatolták volna. További 12 község négy várost alkotva jelentette volna „Budapest-környék” terulletét. ${ }^{34} \mathrm{E}$ két egységböl állt össze „Nagy-Budapest”, ami megfelelt a Párizs körül meghatározott „városi zónának”. Nagy-Budapest körül egy falusias jellegét megtartó védöterület helyezkedett volna el: a 75 községből álló „Budapest-vidék” alkotta Párizshoz hasonlóan a „vidéki zónát”.

2) Az elövárosok beépitésének szabályozása

A párizsi tervben, az önkényes parcellázások megakadályozására építészeti és területfelhasználási szabályzatot készítettek el. A városkörnyék sủrün lakott központi részeinek tehermentesítésére be nem építésre szánt zónákat határoltak le, melyeket szabad, zöld területnek tartottak fenn. Bár a terv alapelve szerint a párizsi agglomeráció ekkorra már elérte maximális lakosságszámát, mégis körülhatároltak későbbi beépítésre alkalmas „tartalék földeket”, melyeket az 1950-es, 60-as években lakótelepek épitésére használtak fel.

Budapesten az eddigi övezeti beosztás helyett a környéket rendeltetés szerint osztották fel lakó-, ipari, zöld-, illetve különleges teruletekre. Itt is felmerült a központ tehermentesítése, ezért intenzív beépítésre alkalmas lakóközpontokat terveztek Zuglóban, Ujjpesten, Köbányán, Kispesten illetve a budai oldalon a Szabadság-hegyen és Krisżtinavárosban. A 
Dunától indulva a Városliget, a régi Lóverseny tér, a Kerepesi út és a Népliget vonalán zöldövezeti gyürủ vette volna körül a pesti oldalt.

A budapesti programnak ugyanakkor nagy elönye volt a párizsival szemben, hogy az elövárosokkal összhangban foglalkozott a föváros rendezésével is, míg ez a Prost-tervben nem szerepelt. ${ }^{35}$

A párizsi városkörnyék rendezési tervét 1939-ben iktatták törvénybe, s a külvárosok rendezése egészen az 1960-ban elfogadott általános rendezési tervig e terv alapján történt.

Budapesten, bár a programot 1947-ben jóváhagyta a fôváros, a Közmunkatanács 1948as megszünése után az annak szerepét átvevö Építéstudományi Központ elutasította. Az államszocialista városvezetés elvetette az elsö, a városkörnyéket egységesen kezelö tervezet elképzeléseit, $s$ helyette egy föleg politikai alapokon hozott intézkẻdés emelkedett törvényeröre. 1949-ben a föváros közvetlen környékét képezö 18 települést közigazgatásilag Budapesthez csatolták. A fơváros területe így több, mint kétszeresére, lakossága egymillióról 1,6 millióra növekedett (2.ábra). ${ }^{36}$

Az elővárosok beolvasztása minden elözetes tervezés nélkül történt. Nem vette figyelembe a föváros érdekeit, hiszen egy olyan pillanatban csatolta hozzá a városkörnyéki területeket, amikor annak finanszírozására a háború után újjáépülö Budapest nem volt képes. Az egyesítés ugyanakkor nem járt együtt e települések városias fejlesztésének megszervezésével sem (az elsó általános rendezési terv 1955-ben készült el). ${ }^{37}$ Az elövárosok rendezésének problémáját tehát ez a döntés nem oldotta meg. Politikai célját azonban elérte, a túlnyomórészt munkások lakta települések beolvasztása megváltoztatta a fơváros társadalmi szerkezetét.

Az 1950-ben érvénybe lépó egyesítés a budapesti várospolitikában az 1949-töl bekövetkező törés szimbólumának is tekinthetô. A városvezetés hagyományos szerveinek megszüntetése és az állami szervek által irányított városvezetés bevezetése véget vetett a várospolitika „lineáris” fejlödésének, amely Párizsban és Budapesten a 19. század végétől lezajlott. A városrendezés centralizált tervezése nem azonos azzal a „tudatos várospolitikával", mely éppen a város irányításában részt vevö, különböző érdekeket képviselő szervek kompromisszumán alapszik. Párizs és Budapest párhuzamos fejlödése 1949-ben magszakadt. Az előbbi a "tudatos várospolitika” útján haladt tovább, míg az utóbbiban a centralizált várostervezés új keretek közé helyezte a város fejlödését.

1949-től a várospolitika irányváltása, a „klasszikus” várostervezéssei szembenálló, új városfejlesztési modellek kialakitása vetett véget Párizs és Budapest párhuzamos fejlödésének. Budapest és Párizs majd egy évszázadig tartó párhuzamos városfejlödését az alábbiakban foglalhatjuk össze: 
Keresztély Krisztina :

A várospolitika változása és az elővárosok helyzete Párizsban és Budapesten (1850-1949)

Tér és Társadalom 9. évf. 1995/1-2. 83-104. p.

TÉT 1995 — 1-2

A várospolitika változása és az elövárosok helyzete...

101

\begin{tabular}{|c|c|c|c|c|}
\hline 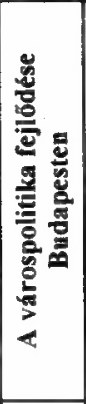 & 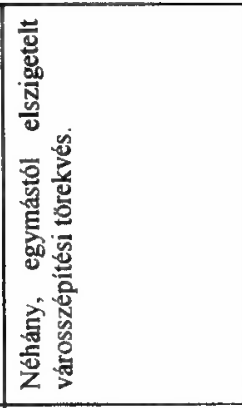 & & 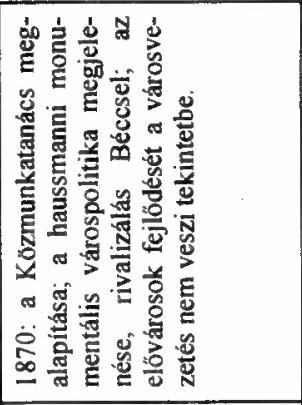 & 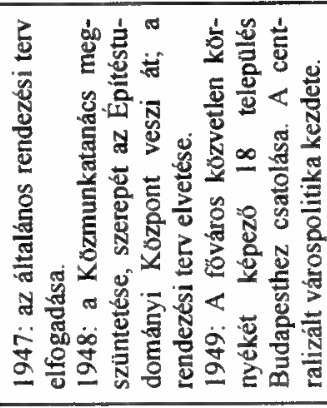 \\
\hline 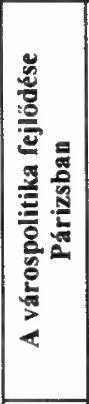 & 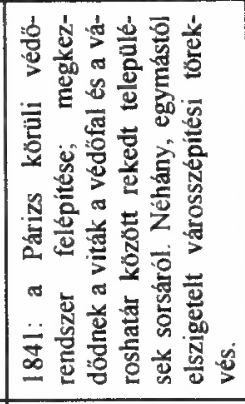 & 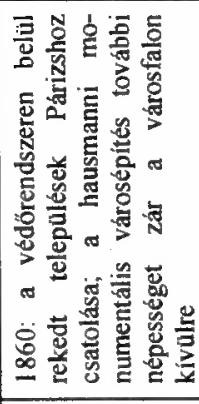 & 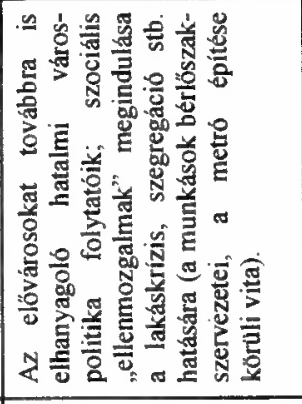 & 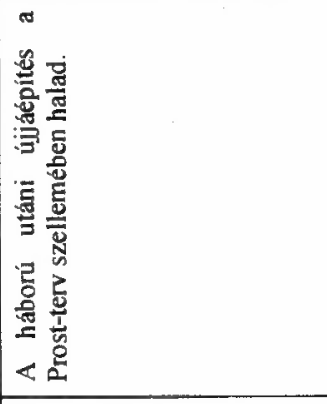 \\
\hline 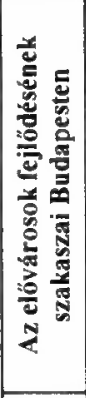 & 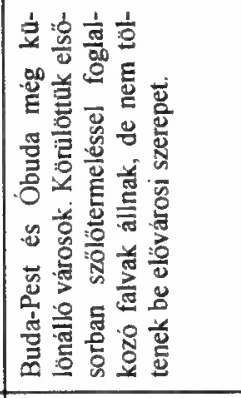 & 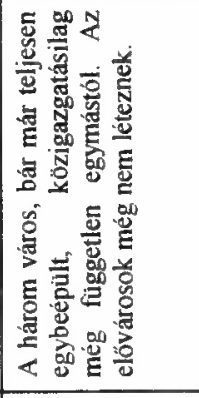 & 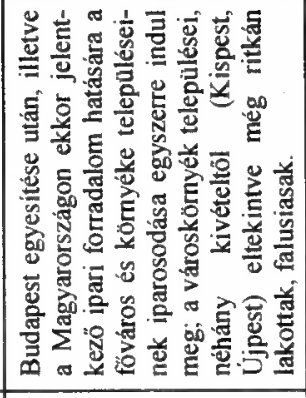 & 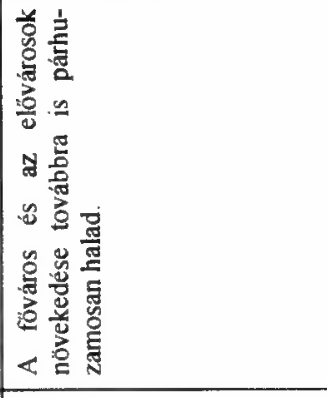 \\
\hline 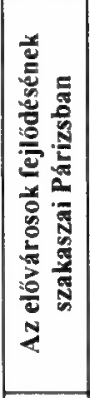 & 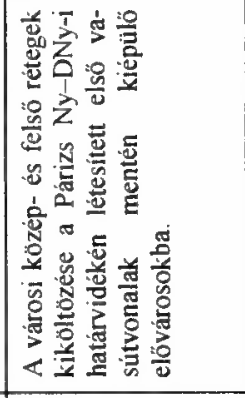 & 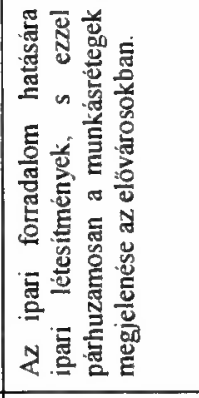 & 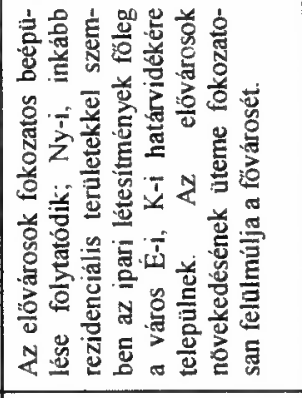 & 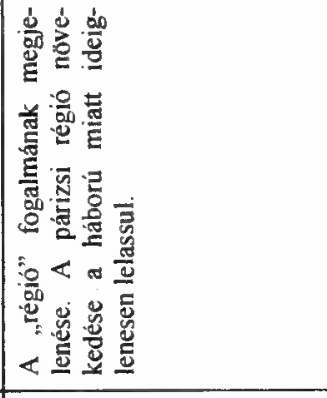 \\
\hline 产 & 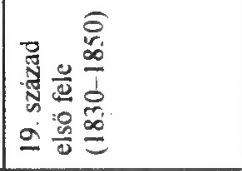 & 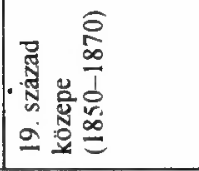 & 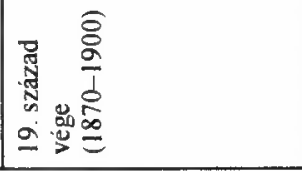 & 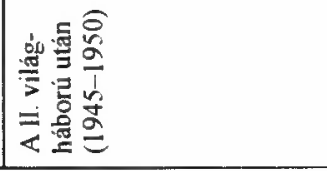 \\
\hline
\end{tabular}




\section{Jegyzetek}

Bastié, J.-Beaujeu-Garnier, J. (szerk.) (1967) Atlas de Paris et de la Région Parisienne, Paris, 139. o. Preisich G. (szerk.) (1972) Budapest jövője. Müszaki Könyvkiadó, Budapest, 8. o.

2 Soulignac, F. (1993) La banlieue parisienne. Paris, La Documentation Française, 6-7. o

3 Soulignac, F. id. mü, 28-32. o. Preisich G. (1969) Budapest városépitésének története III. Müszaki Könyvkiadó, Budapest, 7-13. o

4 Cottereau, A. (1969) Lapparition de l'urbanisme comme action collective: l'agglomération parisienne au début du sičcle. Sociologie du travail, $\mathrm{n}^{\circ} 4 \cdot 342-365$. o.

Cottereau, A. (1970) Les débuts de la plannifcation urbaine dans l'agglomération parisienne Sociologie du travail, $n^{\circ} 4.362-392 . p$

5 A párizsi metró kiépítésének gondolata már a londoni földalatti épülésével egyidóben megszulletett. Az ezt követő, tơbb évtizedig tartó vita két érdekcsoportot állított szembe egymással. Az országos vasútvonalakat irányító monopóliumok az állam támogatásával a metrót a vasúthálózatok összekapcsolására szerették volna felhasználni. Terveik szerint a földalatti vonalainak Párizs föbb pályaudvarait kellett volna osszekơtniük. A városi elöljárók viszont a föváros polgárainak mindennapi kőzlekedését kívánták megkönnyíteni a metróval; a vonalaknak ez alapján az egész várost be kellett volna hálózniuk. A városi kőzlekedés megoldatlansága az 1889-es világkiállításon már súlyos gondokat okozott, így az 1900-as kiállításra mindenképpen valamilyen megoldást kellett találni. Ez a sürgetỏ helyzet a város vezetőinek, s ezáltal egy liberálisabb várospolitikának a győzelméhez vezetett: 1900-ban megindul az első, a várost K-Ny irányban átszelö metróvonal kiépitése.

6 Georges-Eugčne Haussmann bárót 1853-ban nevezte ki III. Napóleon Szajna megye elöljárójává. Müve azóta is állandó vitaforrásul szolgál a várostörténészek számára. Bár e cikkben a „hatalmi” várospolitika legfontosabb egyéniségeként beszélünk róla, szerepe korántsem volt egyértelmủen negativ. Az ő nevéhez füződik Párizs modern városképének kialakitása, s ugyancsak ő volt az első, aki számára a városépités fogalma már nemcsak a szigorúan vett épitészetet, hanem a város egyéb infrastrukturális ellátását (pl. a csatornahálózat) is jelentette. Egyes szerzők szerint (Carmona, M. [1979] Le Grand-Paris) éppen az ö nevéhez füzödik a modern, tudatos várospolitika megteremtése, ő határozta meg Párizs jövőbeli - máig is tartó fejlödésének fỏbb irányait, s e növekedést ő maga tette lehetỏvé azzal, hogy 1859-ben új teruleteket bocsátott a város rendelkezésére

7 Haussmann a $600 \mathrm{~km}$ hosszú csatornahálózattal Párizs utcarendszerének tükőrképét épitette meg a föld alatt. Budapesten 1889 és 1906 kőzött épült ki a városi csatornahálózat

8 Párizs városépítésével kapcsolatban: Marchand, B: (1993) Histoire d’une ville. Seuil, Paris.

Bastié, J. (szerk.) (1964) La Région Parisienne, croissance et urbanisation. In: Lurbanisation Française. Presses Universitaires de France, Paris.

Budapestről: Siklóssy L. (1931) Hogyan épült Budapest? A Fővárosi Kozzmunkák Tanácsa Története 1870-1930. Fővárosi Közmunkák Tanácsa, Budapest.

9 Lextension des limites de Paris, (1913) ln: Commission de l'Extension de Paris, Paris, 200-219. o.

10. Az 1870: X. törvény szövege.

11 Berend T. I.-Ránky Gy. (1961) A Budapest környéki ipari övezet kialakulásának és fejlỏdésének kérdéséhez. In: Tanulmányok Budapest múltjából XIV. Akadémiai Kiadó, 353-575. o.

12 Ưjpest, Rákospalota, Mátyásföld, Almásssy-telep, József fóherceg-telep, Pusztaszentmihály, Kispest, Erzsébetfalva és Kossuthfalva.

13 Pirovits A. (1941) Nagy-Budapest problémája. Közigazgatási Szemle, 84. 355-361. o. Szendy K. (1942) Tanul mány Nagy-Budapeströl. Székesfövárosi házinyomda, Budapest, 23. o.

14 Harrer F. (1908) Nagy-Budapest, Városi Szemle, Budapest 1 évf. Különnyomat, 1-200. o.

15 Bastié, J. (1964) La croissance de la banlieue parisienne. Presses Universitaires de France, Paris, 7-193. o.

16 Szirmai V. (1988) Csinált városok. Magvetó, Budapest, 20-25. o.

17 Soulignac, F. id. mü, 58-62. o.

18 Marchand, B. id. mú, 229-234. o.

19 Marchand, B. id. mú, 281. o.

20 Soulignac, F. id. mü, 84-85. o. 
21 Soulignac, F. id. mủ, 63-65. o.

22 Berend T.-Ránky, Gy. id. mü, 561-570. o.

23 Újpest, Rákospalota, Kispest, Pestszentlörinc, Pestszenterzsébet és Budafok megyei városok, Mátyásfơld, Cinkota, Rákoskeresztúr, Rákosliget, Rákoshegy, Rákoscsaba, Vecsés, Pestszentimre, Soroksár, Csepel, Albertfalva, Budatétény, Pesthidegkút és Békásmegyer községek.

Preisich G. (1969) Budapest városépítésének története lil. Müszaki, Budapest, 26-35. o.

27 Sipö́cz J. (1930) Nagy-Budapest. Pesti Hirlap, febr. 20.

28 Nincs szúkség Nagy-Budapestre! Utazás Nagy-Budapest körül. Magyar Törvényhozók lapja, 1942. 113115, 129. 0 .

Pirovits A. (1930) Pestkörnyék rendezése és Nagy-Budapest. Városok Lapja, 25. évf. 289-291. o.

29 Bastié, C. 279-284. o.

30 Az 1937: VI. törvény szövege.

31 A települések felsorolását 1. 23 . jegyzetpont.

32 A Váci, a Kerepesi, a Ceglédi, a Bécsi, a Soroksári, a Szentendrei, az Andrássy, az Üllöi, a Nagykőrösi és a Dunaparti út.

33 Bessenyei Z. (1940) A Fövárosi Közmunkatanács müködése 1936-40, Székesfövárosi Házinyomda, Budapest.

34 1.: Újpest, Rákospalota és Pestújhely; 2.: Rákosszentmihály, Sashalom és Mátyásföld; 3.: Pestszentlörinc, Kispest és Pesterzsébet; 4.: Budafok, Budatétény és Nagytétény.

35 Preisich G. (1969) 40-46. o.

Soulignac, F. id. mü, 161.o.

Marchand, id. mü, 259. o.

36 A Budapesthez kapcsolt települések: Budafok, Csepel, Kispest, Pesterzsébet, Pestszentlörinc, Rákospalota és Újpest megyei városok, Albertfalva, Békásmegyer, Budatétény, Cinkota, Mátyásfơld, Rákoshegy, Rákoskeresztúr, Rákosliget, Rákosszentmihály, Sashalom és Soroksár községek.

37 Az egykori elővárosok városiasodásának hiányát jól mutatja egy 1970-es adat. Ekkor Budapesten a csatornázott lakások aránya átlagosan 76 százalék volt, miközben néhány peremkerületben ez az arány a 25 százalékot sem érte el.

\title{
TRANSITION OF THE URBAN POLICY AND THE SITUATION OF THE SUBURBS IN PARIS AND BUDAPEST (1850-1949)
}

\author{
KRISZTINA KERESZTÉLY
}

The formation of the suburbs in the 19 th century gradually transformed the structure of the towns. The outskirts, developing at an accelerating pace compared to the towns, had a bigger and bigger share in the provision of urban functions (the moving out of the industry, establishment of residences etc.). The mutual dependence of the town and its environs on each other, at the same time, did not go together with the uniform development of the two areas at that time: The suburbs grew in an isolated, disordered way. The only way to eliminate the contradiction was that the town itself should be responsible for the management of the development and the provision of infrastructure in 
the outskirts. The arrangement of the environs of the town was thus gradually the competence of urban policy, urban planning. This process that lasted for about a century took place parallel in Paris and Budapest, despite the fact that the development of Budapest - for geographical and historical reasons - was belated compared to Paris.

In these two cities the transition of the urban policy and simultaneously the change in the situation of the suburbs can be divided into three periods:

The period of the urban policy of power lasted in Paris from the 1850 s to the turn of the century, in Budapest from the 1873 unification of the city to World War I. The formation of the suburbs took place in this period in both cities. The city leadership only considered the outskirts as "unloading places" at that time and it only relied on them if it was directly necessary for the development of the city. The urban policy supporting the exclusive power of the city can be identified with the name of Haussmann in both cities: The formation of the uniform city image, with giant squares and public buildings started in Budapest, after Paris, due to the effect of Haussmann.

The second phase that lasted from the turn of the century to the 1930s in Paris, and to the end of World War II in Budapest, was a transition from the urban policy of power to the conscious urban policy. Urban policy now realised the significance of the suburbs, the first plans, ideas to arrange the development of the outskirts were made now. There were different reasons for the changes in the two cities: The issue of the arrangement of the suburbs emerged in Paris because of the social problems (especially the housing crisis) reinforced as a consequence of the Haussmann type urban policy, while in Budapest because of the administrative difficulties separating the suburbs from the city. Nevertheless, apart from the debates about the notions, no comprehensive practical results were achieved at that time, thus it was just this time when the suburbs had their most disordered development.

The creation of the first general town arrangement acts (in 1932 in Paris and in 1937 in Budapest) can be considered as the start of the conscious urban policy in both cities. In Paris as soon as in 1934, in Budapest only in 1947 were the first general arrangement plans finalised. These handled the suburbs as uniform areas, divided into zones.

With the formation of the conscious urban policy the problem of the uniform arrangement of the suburbs was solved. Still, the first general arrangement plan was not implemented in Budapest: In 1949 the socialist leadership of the city abandoned the programme. Instead, they annexed the inner suburban ring of Budapest to the city, without an arrangement plan. The change in the direction of the Hungarian urban policy, the formation of new urban development models opposing the "classical" urban planning called a halt to the century-long parallel development of Paris and Budapest in 1949.

Translated by Zoltán Raffay 